\title{
The Role of Hyperinsulenemia as a Risk Factor for Pancreatic Cancer*
}

\author{
Giuseppe Preziosi $^{1 \#}$, Jude A. Oben ${ }^{2}$, Giuseppe Fusai ${ }^{1}$
}

${ }^{1}$ Hepato-Pancreatico-Biliary Surgery and Liver Transplant Unit, Royal Free Hospital, London, United Kingdom; ${ }^{2}$ Centre for Liver and Digestive Health, University College London, Royal Free Hospital, London, United Kingdom.

Email: ${ }^{\#}$ g.preziosi@ucl.ac.uk

Received October $20^{\text {th }}, 2013$; revised November $15^{\text {th }}, 2013$; accepted November $23^{\text {rd }}, 2013$

Copyright (C) 2013 Giuseppe Preziosi et al. This is an open access article distributed under the Creative Commons Attribution License, which permits unrestricted use, distribution, and reproduction in any medium, provided the original work is properly cited. In accordance of the Creative Commons Attribution License all Copyrights (C) 2013 are reserved for SCIRP and the owner of the intellectual property Giuseppe Preziosi et al. All Copyright (C) 2013 are guarded by law and by SCIRP as a guardian.

\begin{abstract}
Background: Pancreatic cancer is associated with a very severe prognosis and identification of risk factors is essential. Diabetes and obesity are both established risk factors, and they both cause hyperinsulenemia. With this review we wished to appraise the evidence of a role of high insulin levels in causing pancreatic cancer. Methods: We searched PubMed, Embase, Cochrane Library and Medline, and all evidence on potential pathophysiology of hyperinsulenemia and pancreatic cancer was included. Meta- and pooled-analysis on epidemiological evidence are reported, as well as individual studies were as appropriate for specific topics (role of therapies, central adiposity and role of physical exercise). Conclusion: Hyperinsulenemia, and possibly hyperestrogenism secondary to a metabolic syndrome, are important elements in the pathogenesis of pancreatic cancer. Modification of certain life-style factors (exercise and weight loss) appears to modify the risk of pancreatic malignancy.
\end{abstract}

Keywords: Pancreatic Cancer; Obesity; Diabetes; Risk Factors; Hyperinsulenemia

\section{Introduction}

Worldwide, pancreatic cancer is the $13^{\text {th }}$ most common cancer but the $8^{\text {th }}$ most common cause of death with little improvement in survival over the last few decades [1]. Surgical resection remains the only potentially curative treatment, but it is feasible in approximately $15 \%-20 \%$ of patients, as the majority present with metastatic diseases [2]. Five-year survival in the operated patients is around $10 \%-15 \%$, and the overall median survival for those with metastatic disease at presentation averages at 6 months $[3,4]$. To date screening remains unfeasible and it is therefore crucial to identify and correct the risk factors associated with the development of pancreatic cancer.

Cigarette smoking is a well-established risk factor [5], but only a quarter of cases of pancreatic cancer are being attributed to it [6]. It is also recognized that diabetes mellitus can be both a cause and a consequence of pancreatic malignancy [7] (Figure 1) [8-10]. More recently it has

*The authors have no conflict of interest to disclose.

${ }^{\#}$ Corresponding author. been suggested that there is sufficient evidence of an increased risk of pancreatic cancer in obese patients [11], with increased body adiposity being an independent risk factor for the malignancy (Figure 2).

These are all potentially reversible risk factors, and therefore great emphasis should be placed on implementing prevention.

Risk of pancreatic cancer in diabetics

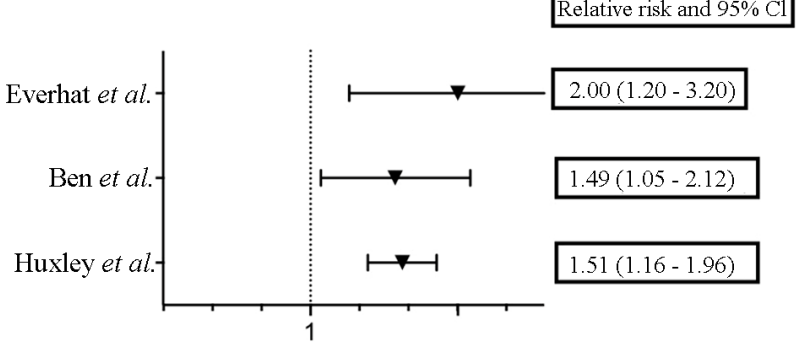

Figure 1. Relative risk and $95 \%$ confidence interval $(\mathrm{Cl})$ of pancreatic cancer for diabetic patients with disease duration between 5 to 10 years [8-10]. 


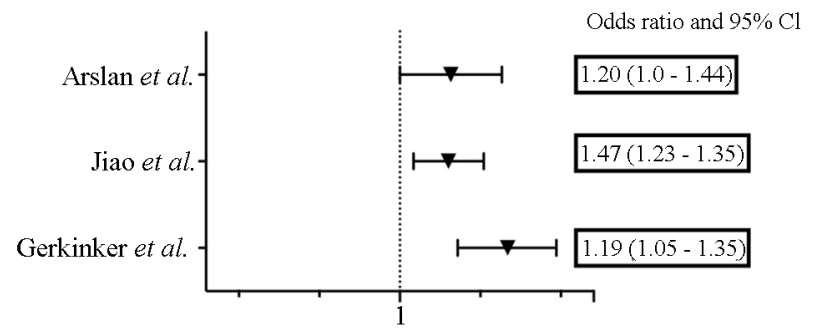

Figure 2. Odds Ratio and $95 \%$ confidence interval for class 1 obese patients (BMI > 30 and $<35)$ versus individual of normal weight $(\mathrm{BMI}<25)$ [12-14].

Obesity and diabetes have in common increased levels of circulating insulin. In fact the combination of insulinresistance, reduced glucose tolerance and hyperinsulinemia is typical of adult diabetes, but it is also present independently in obese individuals in what is known as "metabolic syndrome" [12].

In this review we wished to summarize the evidence linking hyperinsulenemia and pancreatic cancer, which we think is highly relevant given the epidemic of diabetes and obesity across the world.

\section{Methods}

\subsection{Obesity and Hypeinsulenemia}

The common ground between obesity and diabetesappears to be a higher insulin level. Looking at obesity in fact it seems quite clear that increased adiposity increases insulinemia through what is known as "metabolic syndrome" [13-15].

The adipose tissue has effectively endocrine functions, regulating free fatty acids metabolism and releasing cytokines and hormones, which have effects on distant targets [16]. There is also evidence to suggest that obesity can cause cancer in multiple sites and that a central role appears to lie with hyperinsulinaemia [11,17].

In the presence of excess adiposity, an imbalance is generated as a result of an increase in circulating fatty acids, resistin and Tumor Necrosis Factor- $\alpha$ (TNF- $\alpha$ ) by adipose tissue, and reduced release of adiponectin $[18,19]$. This increases the sensitivity of peripheral cells to insulin (reduced insulin tolerance) and hyperinsulenemia. Higher levels of adiponectin have been associated with a reduced risk of pancreatic cancer in smokers [20].

\subsection{The Role of Insulin in Pancreatic Cancer}

Insulin is per se an anabolic hormone, promoting cell growth directly by binding on target cells [21]. The exocrine pancreatic tissue is particularly exposed to it through a portal system from the insulin producing islet cells [22]. This exposure is enhanced by the effect of insulin in increasing localized pancreatic blood flow [23].
A tumorigenic effect on pancreatic tissue has been proved both in vitro $[22,24,25]$ and in animal models [26-31].

Insulin can also act indirectly through an increased production of Insulin-like Growth Factor 1 (IGF1). In fact, both insulin and IGF1 can promote cell growth and inhibit apoptosis [32,33]. Activation of IGF1 receptors has been shown to increase pancreatic cells proliferation [34].

A study examined the expression of 2 neoplastic markers, cytokeratin and Ki67, in pancreatic ductal epithelia from 45 human autopsy and 9 surgical pathology specimens. Obese non-diabetic individuals ductal cells appeared to replicate 10 times more than in lean non-diabetic, whereas, in lean diabetics, the replication rate was 4 times higher than lean non-diabetic [35]. So it appears that markers of pancreatic ductal replication were increased synergistically in obese diabetic subjects.

Ding et al. found that physiologic concentrations of insulin increased pancreatic cancer cell proliferation and glucose utilization by activating mitogen-activated protein kinase, phophotidyl inositol-3 kinase, and glucose transporter1 expression [36].

Three prospective studies have directly investigated abnormal glucose metabolism and the risk of pancreatic cancer. Cumulatively, they reported an increased risk with increasing levels of glucose intolerance, regardless of clinical diabetic status [37-39].

\subsection{Diabetes, Its Treatment and Pancreatic Cancer}

If an increased level of endogenous insulin is associated with a higher risk of pancreatic malignancy, then insulin treatment could also potentially affect this risk.

This was addressed for the first time in 2003 with a case-control study, which assessed if diabetics treated with insulin therapy were more likely to develop pancreatic cancer than those not treated with insulin [40]. It was found that although diabetes was associated with a 2.86-fold increase in the risk for pancreatic cancer, the risk increased to 6.49-fold for those treated with insulin compared to 2.12-fold for those treated with oral hypoglycemic agents. Furthermore, although the duration of insulin treatment had no effect on the high relative risk (RR), longer duration of oral hypoglycemic therapy was associated with a lower RR for the development of pancreatic cancer. This trend was also observed in a multi-centric case-control study, involving 823 patients with pancreatic cancer and 1679 controls [41]. Diabetics with a diagnosis of between 2 - 9 years had an odds ratio (OR) of 1.58, but those who had been treated with insulin had an OR of 3.54, whereas those who had been treated only with oral medication had an OR of 1.78 (Figure 3). 
An overview of the mechanisms responsible for hyperinsulenemia is summarized in Figure 4.

The key factors therefore appears to be insulin-activated enhancement of cell proliferation, and the central role is probably played by insulin/insulin-like growth factor-1 (IGF-1) receptor in the regulation of neoplastic degeneration [42,43].

Further indirect evidence comes form the protective effect of Metformin.

Metformin activates the liver kinaseB1 (LKB1)adenosine monophosphate protein-activated kinase (AMPK) pathway, which inhibits the signaling mechanisms that regulate cellular proliferation [44,45]. LKB1 is a known tumor suppressor, which activates AMPK, a potent inhibitor of mammalian target of rapamycin complex 1 , and disrupts cross talk between insulin/IGF-1 receptors and $G$ protein-coupled receptors, which regulateprotein synthesis and replication [46-48]. These path- ways are criticalregulators of cell replication and have been found to be inhibitedby metformin in pancreatic cancer [26].

\subsection{Hyperinsulenemia and Estrogen Levels}

Another indirect effect of hyperinsulemia is the increased synthesis and bioavailability of both male and female sex hormones [49]. Adipose tissue is the main source of oestrogens in both male and post-menopausal females. In particular, synthesis of oestone and oestradiolare increased and liver production of a sex-hormone binding globulin is reduced. The latter results in an increased bioavailability of both oestrogens and testosterone.

In severely obese men the increase of testosterone drives a negative feedback, inducing a reduced produc tion of gonadotrophin and an increased conversion of testosterone into oestogens. The net effect is an increase

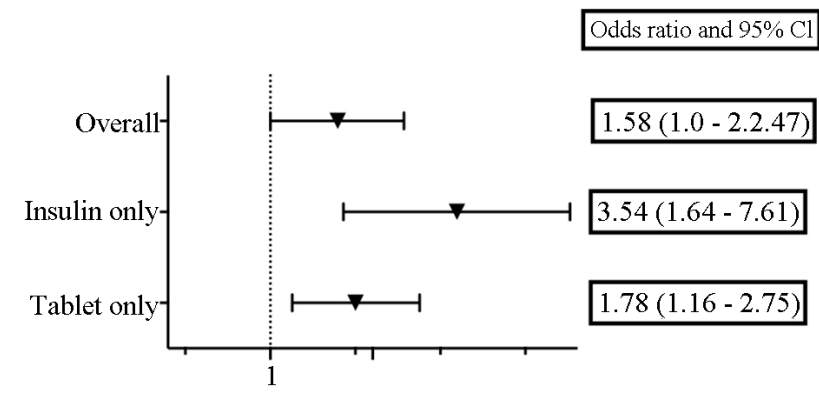

Figure 3. Odds ratio and $95 \%$ confidence interval (Cl) for patients with diabetes mellitus (overall), for those who had been treated with insulin only, and for diabetic patients treated with tablets only.

\section{Pathophysiology of hyperinsulenemia in obesity and diabetes}

Pathophysiology of hyperinsulenemia in obesity and diabetes

Increased adipose tissue

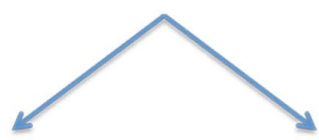

Increased:

circulating fatty acids

- Resistin

- TNFa
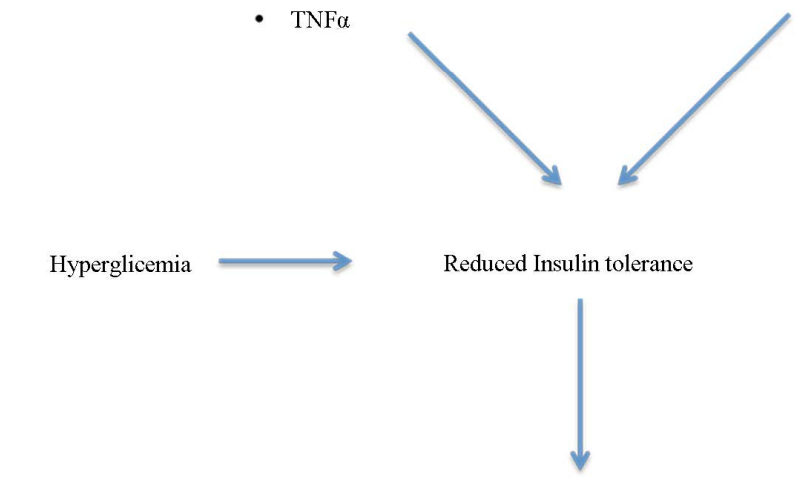

Therapeutic Insulin

Hyperinsulenemia

Figure 4. Pathophysiology of hyperinsulenemia in obesity and diabetes. 
in oestrogens in obese male individuals [49]. A role of hyper-oestrogenism has been suggested in the pathogenesis of cancer [50] and might justify the increase risk of pancreatic malignancy according to parity, age of menarche and possibly oral contraception in obese women compared to normal weight women [51].

\subsection{Central Adiposity and Insulin Resistance}

Central adiposity is more associated with insulin resistance [52]. Most of the studies that have looked at central adiposity (waist circumference, waist to hip ratio and central torso weight gain) to evaluate risk of pancreatic cancer, had positive findings [53-58]. In a North American cohort, a central weight gain was found to confer significant risk in the development of pancreatic cancer, in comparison to peripheral weight gain [53]. In the AARP study waist circumference was positively associated with pancreatic cancer in women, independently from body mass index (BMI). This, however, was not observed in men. Furthermore, no association was found in relation to waist to hip ratio [57].

\subsection{Physical Activity and Pancreatic Cancer}

Physical activity has been shown to improve glucose tolerance and insulin resistance, independently from its effects on weight $[59,60]$. A large study that addressed this topic in relation to pancreatic cancer, involving 2 cohorts of patients, found that physical activity reduced the risk of pancreatic cancer, particularly in overweight patients [61]. However only high levels of physical activity have been found to reduce risk $[62,63]$.

In a meta-analysis, both waist circumference and waist to hip ratio were moderately associated with pancreatic cancer risk [64]. Two pooled analyses demonstrated a positive association with waist to hip ratio only $[65,66]$, with a higher risk for women specifically in one study [66].

Two studies involving patients who underwent bariatric surgery are also consistent with the finding that effective treatment of obesity and concomitant diabetes mellitus reduces cancer risk $[67,68]$.

\section{Conclusion}

Chronic hyperinsulinemia secondary to diabetes or obesity increases the risk of the developing pancreatic cancer. Therapeutic insulin, and treatment with drugs that stimulate insulin secretion, seem to increase the risk of carcinoma by enhanced activation IGF activated signaling pathways. Therapies that reduce insulin levels, such as exercise, weight loss and drugs seem to reduce the risk of pancreatic malignancy. Metformin has a protective effect, by reducing insulin levels and improving glucose metabolism, also due to its specific antineoplastic effects.

High calories intake and poor diabetic control should therefore be tackled at institutional level, in an attempt to reduce the incidence of pancreatic cancer particularly as they can act synergistically.

\section{REFERENCES}

[1] UK CR.

http://info.cancerresearchuk.org/cancerstats/types/pancrea s.

[2] J. T. McPhee, J. S. Hill, G. F. Whalen, M. Zayaruzny, D. E. Litwin, M. E. Sullivan, et al., "Perioperative Mortality for Pancreatectomy: A National Perspective," Annals of Surgery, Vol. 246, No. 2, 2007, pp. 246-253.

http://dx.doi.org/10.1097/01.sla.0000259993.17350.3a

[3] B. Gudjonsson, "Cancer of the Pancreas. 50 Years of Surgery,” Cancer, Vol. 60, No. 9, 1987, pp. 2284-2303. http://dx.doi.org/10.1002/1097-0142(19871101)60:9<228 4::AID-CNCR2820600930>3.0.CO;2-V

[4] J. Ferlay, H. R. Shin, F. Bray, D. Forman, C. Mathers and D. M. Parkin, "Estimates of Worldwide Burden of Cancer in 2008: Globocan 2008,” International Journal of Cancer, Vol. 127, No. 12, 2010, pp. 2893-2917.

http://dx.doi.org/10.1002/ijc.25516

[5] S. Iodice, S. Gandini, P. Maisonneuve and A. B. Lowenfels, "Tobacco and the Risk of Pancreatic Cancer: A Review and Meta-Analysis," Langenbeck's Archives of Surgery, Vol. 393, No., 2008, pp. 535-545. http://dx.doi.org/10.1007/s00423-007-0266-2

[6] D. T. Silverman, J. A. Dunn, R. N. Hoover, M. Schiffman, K. D. Lillemoe, J. B. Schoenberg, et al., "Cigarette Smoking and Pancreas Cancer: A Case-Control Study Based on Direct Interviews," Journal of the National Cancer Institute, Vol. 86, No. 20, 1994, pp. 1510-1516. http://dx.doi.org/10.1093/jnci/86.20.1510

[7] J. T. Magruder, D. Elahi and D. K. Andersen, "Diabetes and Pancreatic Cancer: Chicken or Egg?” Pancreas, Vol. 40, No. 3, 2011, pp. 339-351. http://dx.doi.org/10.1097/MPA.0b013e318209e05d

[8] J. Everhart and D. Wright, "Diabetes Mellitus as a Risk Factor for Pancreatic Cancer. A Meta-Analysis,” JAMA, Vol. 273, No. 20, 1995, pp. 1605-1609. http://dx.doi.org/10.1001/jama.1995.03520440059037

[9] R. Huxley, A. Ansary-Moghaddam, A. Berrington de Gonzalez, F. Barzi, M. Woodward, "Type-II Diabetes and Pancreatic Cancer: A Meta-Analysis of 36 Studies,” British Journal of Cancer, Vol. 92, 2005, pp. 2076-2083. http://dx.doi.org/10.1038/sj.bjc.6602619

[10] Q. Ben, M. Xu, X. Ning, J. Liu, S. Hong, W. Huang, et al., "Diabetes Mellitus and Risk of Pancreatic Cancer: A Meta-Analysis of Cohort Studies," European Journal of Cancer, Vol. 47, No. 13, 2011, pp. 1928-1937. http://dx.doi.org/10.1016/j.ejca.2011.03.003

[11] AICR, World Cancer Research Fund/American Institute 
for Cancer Research, "Food, Nutrition, Physical Activity, and the Prevention of Cancer: A Global Perspective," 2007.

[12] B. B. Kahn and J. S. Flier, "Obesity and Insulin Resistance,” Journal of Clinical Investigation, Vol. 106, No. 4, 2000, pp. 473-481. http://dx.doi.org/10.1172/JCI10842

[13] V. J. Carey, E. E. Walters, G. A. Colditz, C. G. Solomon, W. C. Willett, B. A. Rosner, et al., "Body Fat Distribution and Risk of Non-Insulin-Dependent Diabetes Mellitus in Women. The Nurses' Health Study," American Journal of Epidemiology, Vol. 145, No. 7, 1997, pp. 614619. http://dx.doi.org/10.1093/oxfordjournals.aje.a009158

[14] H. Wahrenberg, K. Hertel, B. M. Leijonhufvud, L. G. Persson, E. Toft and P. Arner, "Use of Waist Circumference to Predict Insulin Resistance: Retrospective Study,” $B M J$, Vol. 330, 2005, pp. 1363-1364.

http://dx.doi.org/10.1136/bmj.38429.473310.AE

[15] P. Bjorntorp, "Metabolic Implications of Body Fat Distribution,” Diabetes Care, Vol. 14, No. 12, 1991, pp. 1132-1143. http://dx.doi.org/10.2337/diacare.14.12.1132

[16] M. W. Rajala and P. E. Scherer, "Minireview: The Adipocyte-At the Crossroads of Energy Homeostasis, Inflammation, and Atherosclerosis," Endocrinology, Vol. 144, No. 9, 2003, pp. 3765-3773. http://dx.doi.org/10.1210/en.2003-0580

[17] A. G. Renehan, M. Tyson, M. Egger, R. F. Heller and M. Zwahlen, "Body-Mass Index and Incidence of Cancer: A Systematic Review and Meta-Analysis of Prospective Observational Studies,” Lancet, Vol. 371, No. 9612, 2008, pp. 569-578. http://dx.doi.org/10.1016/S0140-6736(08)60269-X

[18] G. M. Reaven, "Banting Lecture 1988. Role of Insulin Resistance in Human Disease,” Diabetes, Vol. 37, No. 12, 1988, pp. 1595-1607. http://dx.doi.org/10.2337/diab.37.12.1595

[19] B. L. Wajchenberg, "Subcutaneous and Visceral Adipose Tissue: Their Relation to the Metabolic Syndrome," Endocrine Reviews, Vol. 21, No. 6, 2000, pp. 697-738. http://dx.doi.org/10.1210/er.21.6.697

[20] R. Z. Stolzenberg-Solomon, S. Weinstein, M. Pollak, Y. Tao, P. R. Taylor, J. Virtamo, et al., "Prediagnostic Adiponectin Concentrations and Pancreatic Cancer Risk in Male Smokers," American Journal of Epidemiology, Vol. 168, No. 9, 2008, pp. 1047-1055. http://dx.doi.org/10.1093/aje/kwn221

[21] S. M. Shafie and R. Hilf, "Insulin Receptor Levels and Magnitude of Insulin-Induced Responses in 7,12-Dimethylbenz(a)Anthracene-Induced Mammary Tumors in Rats,” Cancer Research, Vol. 41, 1981, pp. 826-829.

[22] J. A. Williams and I. D. Goldfine, "The Insulin-Pancreatic Acinar Axis,” Diabetes, Vol. 34, No. 10, 1985, pp. 980-986. http://dx.doi.org/10.2337/diab.34.10.980

[23] J. R. Henderson, P. M. Daniel and P. A. Fraser, "The Pancreas as a Single Organ: The Influence of the Endocrine upon the Exocrine Part of the Gland,” Gut, Vol. 22, 1981, pp. 158-167. http://dx.doi.org/10.1136/gut.22.2.158
[24] W. E. Fisher, L. G. Boros and W. J. Schirmer, "Insulin Promotes Pancreatic Cancer: Evidence for Endocrine Influence on Exocrine Pancreatic Tumors," Journal of Surgical Research, Vol. 63, No. 1, 1996, pp. 310-313. http://dx.doi.org/10.1006/jsre.1996.0266

[25] F. Wang, J. Larsson, T. E. Adrian, T. Gasslander and J. Permert, "In Vitro Influences between Pancreatic Adenocarcinoma Cells and Pancreatic Islets,” Journal of Surgical Research, Vol. 79, No. 1, 1998, pp. 13-19. http://dx.doi.org/10.1006/jsre.1998.5393

[26] M. B. Schneider, H. Matsuzaki, J. Haorah, A. Ulrich, J. Standop, X. Z. Ding, et al., "Prevention of Pancreatic Cancer Induction in Hamsters by Metformin,” Gastroenterology, Vol. 120, No. 5, 2001, pp. 1263-1270. http://dx.doi.org/10.1053/gast.2001.23258

[27] J. Liu, K. Kazakoff, P. M. Pour and T. E. Adrian, “The Intracellular Mechanism of Insulin Resistance in the Hamster Pancreatic Ductal Adenocarcinoma Model," Pancreas, Vol. 17, No. 4, 1998, pp. 359-366. http://dx.doi.org/10.1097/00006676-199811000-00006

[28] K. Kazakoff, T. Cardesa, J. Liu, T. E. Adrian, D. Bagchi, M. Bagchi, et al., "Effects of Voluntary Physical Exercise on High-Fat Diet-Promoted Pancreatic Carcinogenesis in the Hamster Model," Nutrition and Cancer, Vol. 26, No. 3, 1996, pp. 265-279. http://dx.doi.org/10.1080/01635589609514483

[29] R. H. Bell Jr., P. J. McCullough and P. M. Pour, "Influence of Diabetes on Susceptibility to Experimental Pancreatic Cancer," The American Journal of Surgery, Vol. 155, No. 1, 1988, pp. 159-164. http://dx.doi.org/10.1016/S0002-9610(88)80274-5

[30] P. M. Pour, K. Kazakoff and K. Carlson, "Inhibition of Streptozotocin-Induced Islet Cell Tumors and N-Nitrosobis (2-oxopropyl)Amine-Induced Pancreatic Exocrine Tumors in Syrian Hamsters by Exogenous Insulin,” Cancer Research, Vol. 50, 1990, pp. 1634-1639.

[31] P. M. Pour and K. Stepan, "Modification of Pancreatic Carcinogenesis in the Hamster Model. VIII. Inhibitory Effect of Exogenous Insulin," Journal of the National Cancer Institute, Vol. 72, 1984, pp. 1205-1208.

[32] M. A. Lawlor and D. R. Alessi, "PKB/Akt: A Key Mediator of Cell Proliferation, Survival and Insulin Responses?” Journal of Cell Science, Vol. 114, No. 16, 2001, pp. 2903-2910.

[33] M. Prisco, G. Romano, F. Peruzzi, B. Valentinis and R. Baserga, "Insulin and IGF-I Receptors Signaling in Protection from Apoptosis," Hormone and Metabolic Research, Vol. 31, No. 2-3, 1999, pp. 80-89. http://dx.doi.org/10.1055/s-2007-978703

[34] E. Ohmura, M. Okada, N. Onoda, Y. Kamiya, H. Murakami, T. Tsushima, et al., "Insulin-Like Growth Factor I and Transforming Growth Factor Alpha as Autocrine Growth Factors in Human Pancreatic Cancer Cell Growth,” Cancer Research, Vol. 50, 1990, pp. 103-107.

[35] A. E. Butler, R. Galasso, A. Matveyenko, R. A. Rizza, S. Dry, P. C. Butler, "Pancreatic Duct Replication is Increased with Obesity and Type 2 Diabetes in Humans," Diabetologia, Vol. 53, No. 1, 2010, pp. 21-26. http://dx.doi.org/10.1007/s00125-009-1556-8 
[36] X. Z. Ding, D. M. Fehsenfeld, L. O. Murphy, J. Permert and T. E. Adrian, "Physiological Concentrations of Insulin Augment Pancreatic Cancer Cell Proliferation and Glucose Utilization by Activating MAP Kinase, PI3 Kinase and Enhancing GLUT-1 Expression,” Pancreas, Vol. 21, No. 3, 2000, pp. 310-320. http://dx.doi.org/10.1097/00006676-200010000-00014

[37] S. M. Gapstur, P. H. Gann, W. Lowe, K. Liu, L. Colangelo and A. Dyer, "Abnormal Glucose Metabolism and pancreatic Cancer Mortality,” JAMA, Vol. 283, No. 19, 2000, pp. 2552-2558.

http://dx.doi.org/10.1001/jama.283.19.2552

[38] S. H. Jee, H. Ohrr, J. W. Sull, J. E. Yun, M. Ji and J. M. Samet, "Fasting Serum Glucose Level and Cancer Risk in Korean Men and Women,” JAMA, Vol. 293, No. 2, 2005, pp. 194-202. http://dx.doi.org/10.1001/jama.293.2.194

[39] R. Z. Stolzenberg-Solomon, B. I. Graubard, S. Chari, P. Limburg, P. R. Taylor, J. Virtamo and D. Albanes, "Insulin, Glucose, Insulin Resistance, and Pancreatic Cancer in Male Smokers,” JAMA, Vol. 294, No. 22, 2005, pp. 28722878. http://dx.doi.org/10.1001/jama.294.22.2872

[40] L. Bonelli, H. Aste, P. Bovo, G. Cavallini, M. Felder, R. Gusmaroli, E. Morandini, P. Ravelli, R. Briglia, L. Lombardo, A. De Micheli and V. Pugliese, "Exocrine Pancreatic Cancer, Cigarette Smoking, and Diabetes Mellitus: A Case-Control Study in Northern Italy,” Pancreas, Vol. 27, No. 2, 2003, pp. 143-149. http://dx.doi.org/10.1097/00006676-200308000-00007

[41] P. Maisonneuve, A. B. Lowenfels, H. B. Bueno-de-Mesquita, P. Ghadirian, P. A. Baghurst, W. A. Zatonski, A. B. Miller, E. J. Duell, P. Boffetta and B. Peter, "Past Medical History and Pancreatic Cancer Risk: Results from a Multicenter Case-Control Study," Annals of Epidemiology, Vol. 20, No. 2, 2010, pp. 92-98. http://dx.doi.org/10.1016/j.annepidem.2009.11.010

[42] M. Pollak, "Insulin and Insulin-Like Growth Factor Signalling in Neoplasia," Nature Reviews Cancer, Vol. 8, No. 12, 2008, pp. 915-928.

[43] E. Rozengurt, J. Sinnett-Smith and K. Kisfalvi, “Crosstalk between Insulin/Insulin-Like Growth Factor-1 Receptors and G Protein-Coupled Receptor Signaling Systems: A Novel Target for the Antidiabetic Drug Metformin in Pancreatic Cancer,” Clinical Cancer Research, Vol. 16, No. 9, 2010, pp. 2505-2511. http://dx.doi.org/10.1158/1078-0432.CCR-09-2229

[44] R. J. Shaw, K. A. Lamia, D. Vasquez, S. H. Koo, N. Bardeesy, R. A. Depinho, M. Montminy and L. C. Cantley, "The Kinase LKB1 Mediates Glucose Homeostasis in Liver and Therapeutic Effects of Metformin," Science, Vol. 310, No. 5754, 2005, pp. 1642-1646. http://dx.doi.org/10.1126/science.1120781

[45] M. Zakikhani, R. Dowling, I. G. Fantus, N. Sonenberg and M. Pollak, "Metformin Is an AMP Kinase-Dependent Growth Inhibitor for Breast Cancer Cells,” Cancer Research, Vol. 66, No. 21, 2006, pp. 10269-10273. http://dx.doi.org/10.1158/0008-5472.CAN-06-1500

[46] K. Kisfalvi, G. Eibl, J. Sinnett-Smith and E. Rozengurt, "Metformin Disrupts Crosstalk between G Protein-Cou- pled Receptor and Insulin Receptor Signaling Systems and Inhibits Pancreatic Cancer Growth," Cancer Research, Vol. 69, No. , 2009, pp. 6539-6545. http://dx.doi.org/10.1158/0008-5472.CAN-09-0418

[47] R. J. Shaw, N. Bardeesy, B. D. Manning, L. Lopez, M. Kosmatka, R. A. DePinho and L. C. Cantley, “The LKB1 Tumor Suppressor Negatively Regulates mTOR Signaling," Cancer Cell, Vol. 6 , No. 1, 2004, pp. 91-99. http://dx.doi.org/10.1016/j.ccr.2004.06.007

[48] D. R. Alessi, K. Sakamoto and J. R. Bayascas. "LKB1Dependent Signaling Pathways," Annual Review of Biochemistry, Vol. 75, 2006, pp. 137-163.

http://dx.doi.org/10.1146/annurev.biochem.75.103004.14 $\underline{2702}$.

[49] A. Tchernof and J. P. Despres, "Sex Steroid Hormones, Sex Hormone-Binding Globulin, and Obesity in Men and Women," Hormone and Metabolic Research, Vol. 32, No. 11-12, 2000, pp. 526-536. http://dx.doi.org/10.1055/s-2007-978681

[50] A. B. Miller, T. H. Barclay, N. W. Choi, M. G. Grace, C. Wall, M. Plante, G. R. Howe, B. Cinader and F. G. Davis, "A Study of Cancer, Parity and Age at First Pregnancy," Journal of Chronic Diseases, Vol. 33, No. 10, 1980, pp. 595-605. http://dx.doi.org/10.1016/0021-9681(80)90002-8

[51] H. B. Bueno de Mesquita, P. Maisonneuve, C. J. Moerman and A. M. Walker, "Anthropometric and Reproductive Variables and Exocrine Carcinoma of the Pancreas: A Population-Based Case-Control Study in The Netherlands," International Journal of Cancer, Vol. 52, No. 1, 1992, pp. 24-29. http://dx.doi.org/10.1002/ijc.2910520106

[52] N. Abate, "Insulin Resistance and Obesity. The Role of Fat Distribution Pattern,” Diabetes Care, Vol. 19, No. 3, 1996, pp. 292-294.

[53] A. V. Patel, C. Rodriguez, L. Bernstein, A. Chao, M. J. Thun and E. E. Calle, "Obesity, Recreational Physical Activity, and Risk of Pancreatic Cancer in a Large U.S. Cohort," Cancer Epidemiology, Biomarkers \& Prevention, Vol. 14, No. 2, 2005, pp. 459-466. http://dx.doi.org/10.1158/1055-9965.EPI-04-0583

[54] S. C. Larsson, J. Permert, N. Hakansson, I. Naslund, L. Bergkvist and A. Wolk, "Overall Obesity, Abdominal Adiposity, Diabetes and Cigarette Smoking in Relation to the Risk of Pancreatic Cancer in Two Swedish Population-Based Cohorts,” British Journal of Cancer, Vol. 93, No. 11, 2005, pp. 1310-1315. http://dx.doi.org/10.1038/sj.bjc.6602868

[55] A. Berrington de Gonzalez, E. A. Spencer, H. B. Bueno-de-Mesquita, A. Roddam, R. Stolzenberg-Solomon, J. Halkjaer, et al., "Anthropometry, Physical Activity, and the Risk of Pancreatic Cancer in the European Prospective Investigation into Cancer and Nutrition," Cancer Epidemiology, Biomarkers \& Prevention, Vol. 15, No. 5, 2006, pp. 879-885. http://dx.doi.org/10.1158/1055-9965.EPI-05-0800

[56] A. Ansary-Moghaddam, R. Huxley, F. Barzi, C. Lawes, T. Ohkubo, X. H. Fang, S. H. Jee, M. Woodward and Asia 
Pacific Cohort Studies Collaboration, "The Effect of Modifiable Risk Factors on Pancreatic Cancer Mortality in Populations of the Asia-Pacific Region," Cancer Epidemiology, Biomarkers \& Prevention, Vol. 15, No. 12, 2006, pp. 2435-2440.

http://dx.doi.org/10.1158/1055-9965.EPI-06-0368

[57] R. Z. Stolzenberg-Solomon, K. Adams, M. Leitzmann, C. Schairer, D. S. Michaud, A. Hollenbeck, A. Schatzkin and D. T. Silverman, "Adiposity, Physical Activity, and Pancreatic Cancer in the National Institutes of HealthAARP Diet and Health Cohort," American Journal of Epidemiology, Vol. 167, No. 5, 2008, pp. 586-597. http://dx.doi.org/10.1093/aje/kwm361

[58] J. Luo, K. L. Margolis, H. O. Adami, A. LaCroix and W. Ye, "Obesity and Risk of Pancreatic Cancer among Postmenopausal Women: The Women's Health Initiative (United States),” British Journal of Cancer, Vol. 99, No. 3, 2008, pp. 527-531. http://dx.doi.org/10.1038/sj.bjc.6604487

[59] Y. Oshida, K. Yamanouchi, S. Hayamizu and Y. Sato, "Long-Term Mild Jogging Increases Insulin Action Despite no Influence on Body Mass Index or VO2 Max," Journal of Applied Physiology, Vol. 66, No. 5, 1989, pp. 2206-2210.

[60] D. E. Kelley and B. H. Goodpaster. "Effects of Physical Activity on Insulin Action and Glucose Tolerance in Obesity," Medicine \& Science in Sports \& Exercise, Vol. 31, No. 11, 1999, pp. S619-S623. http://dx.doi.org/10.1097/00005768-199911001-00021

[61] D. S. Michaud, E. Giovannucci, W. C. Willett, G. A. Colditz, M. J. Stampfer and C. S. Fuchs, "Physical Activity, Obesity, Height, and the Risk of Pancreatic Cancer," JAMA, Vol. 286, No. 8, 2001, pp. 921-929. http://dx.doi.org/10.1001/jama.286.8.921

[62] B. Isaksson, F. Jonsson, N. L. Pedersen, J. Larsson, M. Feychting and J. Permert "Lifestyle Factors and Pancreatic Cancer Risk: A Cohort Study from the Swedish Twin Registry,” International Journal of Cancer, Vol. 98, No.
3, 2002, pp. 480-482. http://dx.doi.org/10.1002/ijc.10256

[63] A. J. Hanley, K. C. Johnson, P. J. Villeneuve and Y. Mao, "Physical Activity, Anthropometric Factors and Risk of Pancreatic Cancer: Results from the Canadian Enhanced Cancer Surveillance System," International Journal of Cancer, Vol. 94, No. 1, 2001, pp. 140-147. http://dx.doi.org/10.1002/ijc.1446

[64] D. Aune, D. C. Greenwood, D. S. Chan, R. Vieira, A. R. Vieira, D. A. Navarro Rosenblatt, J. E. Cade, V. J. Burley and T. Norat, "Body Mass Index, Abdominal Fatness and Pancreatic Cancer Risk: A Systematic Review and NonLinear Dose-Response Meta- Analysis Of Prospective Studies," Annals of Oncology, Vol. 23, No. 4, 2011, pp. 843852.

[65] J. M. Genkinger, D. Spiegelman, K. E. Anderson, L. Bernstein, P. A. van den Brandt, E. E. Calle, et al., "A Pooled Analysis of 14 Cohort Studies of Anthropometric Factors and Pancreatic Cancer Risk,” International Journal of Cancer, Vol. 129, No. 7, 2011, pp. 1708-1717. http://dx.doi.org/10.1002/ijc.25794

[66] A. A. Arslan, K. J. Helzlsouer, C. Kooperberg, X. O. Shu, E. Steplowski, H. B. Bueno-de-Mesquita, et al., "Anthropometric Measures, Body Mass Index, and Pancreatic Cancer: A Pooled Analysis from the Pancreatic Cancer Cohort Consortium (PanScan),” JAMA, Vol. 170, No. 9, 2010, pp. 791-802. http://dx.doi.org/10.1001/archinternmed.2010.63

[67] N. V. Christou, M. Lieberman, F. Sampalis and J. S. Sampalis, "Bariatric Surgery Reduces Cancer Risk in Morbidly Obese Patients," Surgery for Obesity and Related Diseases, Vol. 4, No. 6, 2008, pp. 691-695. http://dx.doi.org/10.1016/j.soard.2008.08.025

[68] T. D. Adams, A. M. Stroup, R. E. Gress, K. F. Adams, E. E. Calle, S. C. Smith, R. C. Halverson, S. C. Simper, P. N. Hopkins and S. C. Hunt, "Cancer Incidence and Mortality after Gastric Bypass Surgery,” Obesity, Vol. 17, No. 4, 2009, pp. 796-802. http://dx.doi.org/10.1038/oby.2008.610 